\title{
Commercial Glue Sniffing and Child Health: Indian Street Children are at a Risk
}

\author{
Nandan Kumar Mondal* \\ Artificial Organ Laboratory, Department of Surgery, University of Maryland School of Medicine, USA
}

Children are the source of hope and inspiration for the society. That is why they have the right to be brought up in a positive environment. But there are many children in the world who have become synonymous with social deprivation at its worst. Children who are working and living on the streets are found throughout the nation. Street children constitute a marginalized population in most urban centers of the world. There are major difficulties in trying to estimate the number of street children and the magnitude of hardship they experience. In their marginalized state they constitute a truly "hidden" population who were not covered by nor find place in the national census, educational or health data, largely because they have no fixed address [1]. This problem is further compounded by the fact that they are also a highly mobile population. However, it is speculated that between 100,000 and 125,000 children live on the streets and railway stations of India's major cities, and that more than half of them have some form of drug addiction.

Street boys living at different Indian railway stations of West Bengal, take care of themselves and each other in an otherwise uncaring environment and surviving through begging, petty theft or hawking goods on the platforms. Most of the paltry sum they earn is spent on tobacco or on tube of Glue (locally known as 'Dendrite' which is an industrial contact adhesive and rubber cement brand marketed as glue sticks, tubes and cans in India and South Asia, mainly in Eastern India, Bangladesh and Bhutan) that is a particular favorite with those children. This golden colored industrial glue (often called as 'golden glue') containing organic solvents is cheap and readily available and provides faster onset of action and the regular 'high' [2,3]. Investigators believe that the addicts can be exposed to several thousand parts per million (2,000-30,000 ppm) of organic solvents within a few minutes [4]. The kids squeeze Glue onto a rag and huff its fumes through the mouth.

Although these products are not classified as drugs because they are not intended to be used to achieve intoxication, young children and adolescents can easily obtain them and are among those most likely to abuse them [5]. Besides addiction, they're usually victims of abuse and harassment, and are extremely vulnerable to trafficking, sex trade and child labor [6]. Inhalant abuse/dependence has been reported from various parts of the world [7-10]. Drug usage among minors has created a global generation of addicted and often abandoned children bereft of family support, education and social skills. There are epidemiological reports indicating that chronic exposure to abuse solvents can produce loss of appetite [5]; however, the mechanisms involved in these effects are not well understood. It's sad that kids would come to that.

Our previous reports suggested that tobacco smoking and/or chewing habit among street boys is associated with increased frequency of micronucleus and $\gamma-\mathrm{H} 2 \mathrm{AX}$ foci formation in oral mucosa, implying chromosomal and DNA damage respectively [11]. Additional habit of sniffing/huffing of industrial glue enhances the severity of genotoxic changes in buccal epithelial cells of these children. We also observed marked increase in argyrophilic nuclear organizer region (AgNOR) in buccal epithelial cells of glue-addicted children, suggesting upregulation of ribosome biogenesis in these cells [12]. Taken together, these studies indicate genetic changes in oral mucosa of street boys in association with tobacco and glue sniffing or huffing habit. So it is necessary to campaign biosafety and health education programme explaining the adverse health effects of inhalant abuse by the young futures throughout the nation. Genetic markers could provide a useful means of detecting early mutagenic events for assessing cancer risk associated with inhalant abuse which is quite prevalent in developed countries also. In the United States, for example, nearly $20 \%$ of young persons have experimented with inhalants at least once by the time they are in eighth grade and the mean age of first-time inhalant abuse is 13 years [13]. More importantly, children who abuse inhalants early in life are more likely later to use other illicit drugs. Thus inhalant abuse intervention programs seem important from the community health perspective also.

\section{References}

1. Benegal V, Bhushan K, Seshadri S, Karott M (1998) Drug Abuse Among Street Children in Bangalore. Monograph Funded by CRY.

2. Basu D, Jhirwal OP, Singh J, Kumar S, Mattoo SK (2004) Inhalant abuse by adolescents: a new challenge for Indian physicians. Indian J Med Sci 58: 245249

3. Seth R, Kotwal A, Ganguly KK (2005) Street and working children in Delhi, India, misusing toluene: an ethnographic exploration. Subst Use Misuse 40 1659-1679.

4. Marjot R, McLeod AA (1989) Chronic non-neurological toxicity from volatile substance abuse. Hum Toxicol 8: 301-306

5. Inhalants (2004) National Institute on Drug Abuse, National Institutes of Health U.S. Department of Health \& Human Services.

6. Gupta SK, Bali S, Jiloha RC (2009) Inhalant abuse: an overlooked problem Indian J Psychiatry 51: 160-161.

7. Weir E (2001) Inhalant use and addiction in Canada. CMAJ 164: 397

8. Ramon MF, Ballesteros S, Martinez-Arrieta R, Torrecilla JM, Cabrera J (2003) Volatile substance and other drug abuse inhalation in Spain. J Toxicol Clin Toxicol 41: 931-936.

9. Wu LT, Pilowsky DJ, Schlenger WE (2004) Inhalant abuse and dependence among adolescents in the United States. J Am Acad Child Adolesc Psychiatry 43: 1206-1214.

*Corresponding author: Nandan Kumar Mondal, Artificial Organ Laboratory, Department of Surgery, University of Maryland School of Medicine, 10 South Pine Street, Baltimore, Maryland 21201, USA, Tel: 410-706-4549; Fax: 410-706-0311; E-mail: nkmondal@smail.umaryland.edu

Received May 12, 2013; Accepted May 16, 2013; Published May 18, 2013

Citation: Mondal NK (2013) Commercial Glue Sniffing and Child Health: Indian Street Children are at a Risk. J Biosafety Health Educ 1: e108. doi:10.4172/23320893.1000e108

Copyright: (c) 2013 Mondal NK. This is an open-access article distributed under the terms of the Creative Commons Attribution License, which permits unrestricted use, distribution, and reproduction in any medium, provided the original author and source are credited. 
Citation: Mondal NK (2013) Commercial Glue Sniffing and Child Health: Indian Street Children are at a Risk. J Biosafety Health Educ 1: e108. doi:10.4172/2332-0893.1000e108

Page 2 of 2

10. Mondal NK, Ghosh S, Ray MR (2011) Micronucleus formation and DNA damage in buccal epithelial cells of Indian street boys addicted to gasp 'Golden glue'. Mutat Res 721: 178-183.

11. Mondal NK, Ghosh S, Ray MR (2011) Quantitative analysis of AgNOR proteins in buccal epithelial cells of Indian street boys addicted to gasp 'golden glue'. Exp Toxicol Pathol 63: 677-681.
12. McGarvey EL, Clavet GJ, Mason W, Waite D (1999) Adolescent inhalant abuse: environments of use. Am J Drug Alcohol Abuse 25: 731-741.

13. McGarvey EL, Clavet GJ, Mason W, Waite D (1999) Adolescent inhalant abuse: environments of use. Am J Drug Alcohol Abuse 25: 731-741. 